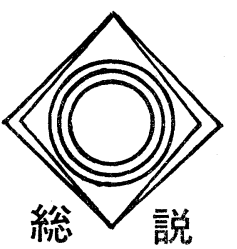

\section{1. はじめに}

近年, 石油事情のひっ迫とともに，石油に代わるエ ネルギーへの要請がにわかに高まってきた。この石油 代替エネルギーとして検討されているもののらちで, 太陽エネルギーはその絶対量の点で最も期待されてい るものの一つである。地球上の生物体は化学熱力学的 には太陽エネルギーにより形成されたものと言える。 メタン発酵は生物体由来の有機物から天然ガスの主成 分であるメタンを生産できることから，太陽エネルギ 一燃料化システムとして利用することができるのであ る。有機物としてセルロースを例にとれば，七ルロ一 スは炭酸ガスと水から光合成により合成されたもので あるが，これはメタン発酵菌により最終的にはメタン と炭酸ガスに分解される。この生成ガスる人間が燃料 として利用すれば，クローズドシステムが出来上がる (図 1 )。

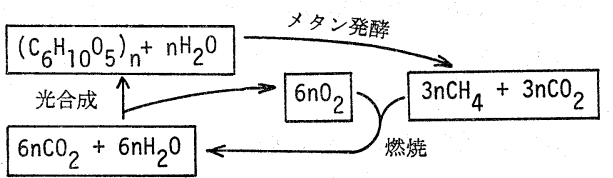

図 1 太陽エネルギ一燃料化システム

このメタン発酵に関する微生物の生理, 生態, 利用 に関する知識は近年，急速に増大しており多くの総説

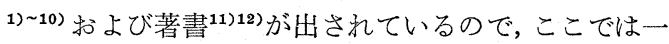
般的な解説は重要なものにとどめ, 出来るだけ新しい 情報および最近のトピックを紹介したい。

\section{2.メタン発酵菌の生理および生態}

メタン発酵菌は, 有機物を酢酸, プロピオン酸, $n$ 酪酸などの有機酸に分解する細菌と，有機酸をメタン と炭酸ガスに分解するメタン生成菌から成っている。 それらの有機酸を直接メタンと炭酸ガスに分解するメ タン生成菌を分離したとの報告があるが，現在ではプ ロピオン酸， $n$-酪酸を基質とするものについては，さ

応用技術部廃水処理研究室

干305 茨城県筑波郡谷田部町東1-1-3
微生物工業技術研究所 田中- 裕

らに二種以上の菌の混合体であり純粋菌ではないので はないかとみなされている7。

現在までに報告されている(13) -24) メタン生成菌とそ の性質を表 1 に示すが，プロピオン酸， $n$-酪酸など $\mathrm{C}_{3}$ 以上の有機酸を基質とするものはない。これらの有機 酸が嫌気的環境で, ぞらいう微生物によって, メタン 生成菌が利用できる基質に変換されるのか，まだ明ら かにされていない。

メタン生成菌の生育温度は, $65 \sim 70^{\circ} \mathrm{C}$ に至適温度を もつ Methanobacterium thermoautotrophicum を除 けばすべて $30 \sim 45^{\circ} \mathrm{C}$ に至適温度をもつ中温菌である。 混合培養系による，いわゆるメタン発酵は，30４0 ${ }^{\circ} \mathrm{C}$ (中温域) おょび $50 \sim 60^{\circ} \mathrm{C}$ (高温域) といら二つの至 適温度領域が知られており，中温域は中温菌の至適温 度にほぼ一致しているが，高温域は M. thermoautoirophicum の至適温度より $10^{\circ} \mathrm{C}$ 程低い。高温域に至適 温度を有するメタン生成菌が存在するが未だ発見され ていないのか, メタン発酵に関与する非メタン生成菌 の至適温度が，50〜 $60^{\circ} \mathrm{C}$ かそ以下にあるため，全体 として $50 \sim 60^{\circ} \mathrm{C}$ 至適温度があるように見えるのか， 今後の研究に期待したい。

メタン生成菌の至適 $\mathrm{pH}$ は報告されていないものも あるが，その場合にはその菌を使った実験に用いられ ている温度を示し，?をつけている(表 1 )。すべての 菌が $\mathrm{pH} 6-8$ の範囲内に至適 $\mathrm{pH}$ があるようである。

既知のメタン生成菌はすべて，水素／炭酸がスを利 用するが，酢酸，ギ酸，メタノールを利用できるのは そのうちの一部の菌のみである。Zeikus ら ${ }^{24)}$ は,

Methanosarcina barkerii Ł M. thermoautotrophicum は水素存在下では酢酸を利用するが，水素が存在しな いと酢酸を利用しない事を示した。しかし，その後， Mah ${ }^{21)}$ は, 水素がなくても酢酸を利用できるメタン 生成菌 Methanosarcina strain 227 を分離した。水素 /炭酸ガス系, 酢酸系, および酢酸／水素系のメタン 生成反応の反応式と生成自由エネルギーは次式のよう になる ${ }^{24)}$ 
表 1 メタン生成菌とその性質 ${ }^{13) ~ 24)}$

\begin{tabular}{|c|c|c|c|c|c|}
\hline 菌 & 名 & 起 源 & 基 & 至適温度 & 至適 $\mathrm{dH}$ \\
\hline Methanobacterium & arbophilicun & 湿った木 & $\mathrm{H}_{2} / \mathrm{CO}_{2}$ & $30-37^{\circ} \mathrm{C}$ & $7.5-9.0$ \\
\hline " & formicicum & 泥, 污泥 & $\mathrm{H}_{2} / \mathrm{CO}_{8}$, ギ酸 & $38-45$ & $?$ \\
\hline "1 & mobile & ルーメン & $\mathrm{H}_{2} / \mathrm{CO}_{8}$, ギ酸 & $40-43$ & $6.1-6.9$ \\
\hline " & ruminantium & ルーメン & $\mathrm{H}_{2} / \mathrm{CO}_{2}$, キ酸 & 37 & $6.0-8.0$ \\
\hline " & thermoautotrophicus & 污 泥 & $\mathrm{H}_{2} / \mathrm{CO}_{2}, \mathrm{H}_{2} /$ 酢酸 & $65-70$ & $7.0-7.6$ \\
\hline "1 & strain $\mathrm{AZ}$ & 污 泥 & $\mathrm{H}_{2} / \mathrm{CO}_{2}$ & $33-40$ & $6.8-7.2$ \\
\hline " & strain $\mathrm{MOH}$ & $\begin{array}{l}\text { Methanobacillus } \\
\text { omelianskii }\end{array}$ & $\mathrm{H}_{2} / \mathrm{CO}_{2}$ & $40 ?$ & $7.0 ?$ \\
\hline Methanococcus & vannielii & 泥 & $\mathrm{H}_{2} / \mathrm{CO}_{2}$,ギ酸 & $30-40$ & 8.0 \\
\hline Methanosarcina & barkeri & 泥, 污泥 & $\mathrm{H}_{2} / \mathrm{CO}_{2}, \mathrm{H}_{2} /$ 酶酸, メタノー儿 & ル $30 ?$ & 7.0 \\
\hline " & strain 227 & 污 泥 & $\mathrm{H}_{2} / \mathrm{CO}_{2}$, 酶酸, メタノール & $35 ?$ & $7.0 ?$ \\
\hline Methanospirillum & hungatii & 污 泥 & $\mathrm{H}_{2} / \mathrm{CO}_{2}$,ギ酸 & 35 & 7.0 \\
\hline
\end{tabular}

$4 \mathrm{H}_{2}+\mathrm{HCO}_{3}^{-} \longrightarrow \mathrm{CH}_{4}+2 \mathrm{H}_{2} \mathrm{O}+\mathrm{OH}^{-}$ $\Delta G^{\prime \prime}=-32.3 \mathrm{kcal} / \mathrm{mole}(\mathrm{pH} 7)$

$\mathrm{CH}_{3} \mathrm{COO}^{-}+\mathrm{H}_{2} \mathrm{O} \longrightarrow \mathrm{CH}_{4}+\mathrm{HCO}_{3}^{-}$

$\Delta G^{0 \prime}=-6.71 \mathrm{kcal} / \mathrm{mole}(\mathrm{pH} 7)$

$\mathrm{CH}_{3} \mathrm{COO}^{-}+4 \mathrm{H}_{2}+\mathrm{H}^{+} \longrightarrow 2 \mathrm{CH}_{4}+2 \mathrm{H}_{2} \mathrm{O}$ $\Delta G^{0 \prime}=-39 \mathrm{kcal} / \mathrm{mole}(\mathrm{pH} 7)$

M. strain 227が反応式(2)により小さなエネルギーを得 ながらどのように ATPを生産し, 増殖しているのか, 今後の研究を待たねばならない。

このよらに種々のメタン生成菌の生理が明らかにさ れつつある一方，メタン生成菌と非メタン生成菌との 共生関係も次第に明らかにされてきている。

Bryant $5^{19)}$ は 10 年以上前に始めてこの共生関係を 純粋菌のレベルで明らかにした。彼らは, エタノール からメタンを生産する細菌と考えられていた Methanobacterium omelianskii が実はエタノールから水素 を生産する細菌 Methanobacterium strain $\mathrm{MOH}$ と 水素／炭酸ガスからメタンを生産する細菌 $\mathrm{S}$ 菌の混合 体である事を示したのである。

その後, このS菌の性質を調べるために, S 菌と Methanobacterium ruminantium との共生関係も調 ベられた ${ }^{26)}$ が， S菌は M. ruminantium の存在また は非存在下にエタノール，n-プロパノール，n-ブタノ 一ル,イソブタノール，n-ペンタノール，アセトアル デヒド，オキザロ酢酸，ピルビン酸を利用するが，水 素存在下ではこれらのものを利用して生育できない事 が示された。すなわちメタン生成菌 $\mathrm{MOH}$ 株や $M$. ruminantium はS 菌が生産する水素を消費する事に より, 結果的にS 菌の生育を促すといら共生関係を有 している事がわかったのである。

Scheifinger $5^{27}$ は嫌気性菌 Selenomonas rumina- ntium を M. ruminantium や $\mathrm{MOH}$ 株と混合培養 する事により，S. ruminantium の水素生産量が60～ 90 倍増大する事を示した。また，気相を炭酸ガス 100 \%で培養した場合，S. ruminantium 単独では，乳酸 やグリセリンから水素は生成しないが，M. ruminantium や $\mathrm{MOH}$ 株との混合培養では水素を生成する 事を示した。

Weimer と Zeikus は28)高温性のメタン生成菌 $M$. thermoautotrophicum と高温性のセルロース分解菌

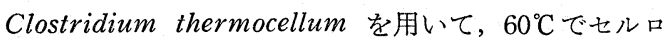
一スでの生育を調べ，両者の混合培養は生育とセルロ 一ス分解の開始の誘導期を短くする事, 水素および酢 酸の生産を増やし，エタノール生産を減らす事を示し た。

Bryant らは29) 下水污泥の嫌気性消化槽よりエタノ 一ル/炭酸ガス系で集積培養を行い，Desulfovibrio vulgaris と思われる硫酸還元菌と, Methanobacterium formicicum に似たメタン生成菌を分離し, その硫酸還 元菌は, このメタン生成菌と混合培養すると, エタノ 一ルや乳酸を利用して生育し，水素を生産する事を示 した。D. vulgaris の典型株や Desulfovibrio desulfuricans むメタン生成菌らの混合培養で, 同様の結果 を得ている。Desulfovibrio と $\mathrm{MOH}$ 株をエタノール， 乳酸またはピルビン酸で生育させる場合, 硫酸イオン の添加に比例してメタンの生成は減少した。

Lathan と Wolin (20) メタン生成菌 M. ruminantium とセルロース分解菌 Ruminococcus flavefaciens を用いてセルロースの発酵を調べ， R. flavefaciens の単独培養に比べて混合培養では, 酢酸が主生産 物になり，コハク酸およびギ酸が減少し，水素が生成 するかわりにメタンが生成する事を示した。 
Chen と Wolin は21) S. ruminantium inantium がすでに生育している培養液にくり返し移 植する事によって，S. ruminantium によるグルコー スや乳酸からの水素生成が増大する事を示した。 $S$. ruminantium 単独ではグルコースからの主生産物は 乳酸であるが, メタン生成菌との混合培養で㥒酸の 生成が減り酢酸の生成が増加した。乳酸を基質とした 場合にはS. ruminantium 単独ではプロピオン酸, 酢 酸, および炭酸ガスを生産するが，メタン生成菌との 混合培養ではプロピオン酸生産が減り, 酢酸生産が増 加した。彼らの結果をS. rminantium によるグルコ 一ス拉よび乳酸代謝系のメタン生成菌の共存による変 化ということでまとめると図2 のようになる。実線が メタン生成菌の共存により強められた流れである。

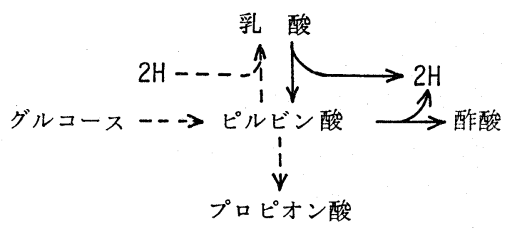

図 2 Selenomonas ruminantium による グルコースおよび乳酸の代謝 ${ }^{31)}$

Ward らは ${ }^{32)}$ 酰酸および無機塩を含む培地で 2 年間 集積培養を行った培養系から，栄養要求の高い非入夕 ン生成菌を分離し,この菌がアミノ酸, ペプチド, プリ ン塩基, ビタミン $\mathrm{B}_{12}$, 打よび他のビタミン類を要求 し，グルコース，マニトール，デンプン，ピルビン 酸, システィン, リジン, ロイシン, イソロイシン, アルギニン, およびアスパラギンが生育と水素生産を 促進した。酶酸はこの菌汉取り込まれも代謝もされな かった。酥酸はこの系では唯一の炭素源であるから, メタン生成菌がこの菌のための基質や生育因子を生産 しているものと推定された。

以上の上らに種々の有機物のメタン発酵が行われて いる混合培養系から菌を純粋に分離する事により，メ タン生成菌と非メタン成生菌との, 基質や生育因子や 代謝系の点での共生関係が次々と明らかにされてきて いる。

\section{3. メタン発酵菌の利用}

メタン発酵法は嫌気性消化法とも呼ばれ, 従来から 下水污泥処理, 畜産廃水処理, 産業廃水処理などに利 用され，技術的改良も加兄られて来たが，最近メタン 発酵の原料る広く検討され始好て抢り，特に米国沶 いては，非常に活発に研究が行われている。

ロサンジェルスなどでは 20 年以上前から都市ゴミの
ハタン発酵が行われているという ${ }^{33)}$ 。わが国でも, 通 産省工業技術院の「資源再生利用技術システムの研究 開発)（昭和 48 年〜 54 年)の一環として都市ゴミから仕 分けされた厨芥類のメタン発醳が検討されている ${ }^{34)}$ 。

また，わが国においては三次処理（活性污泥処理の 次に行ら高次処理）は，まだあまり普及していない が，米国では広大なラグーンに二次处理水を導いて， S S (浮遊物質) や残存 BOD を高度に除去する方法 が一般にとられているそらである ${ }^{38)}$ このラグーンで 増殖する藻類が沈殿し, 嫌気的分解が起こると, 水質 の悪化をひき起こすことから, 藻類を濃縮分離し, メ タン発酵の原料とすることが検討されたのは 20 年以上 前のことである ${ }^{35)}$ 。

Golueke と Oswald (अ83)37) これを一歩進めて, 太 陽エネルギーで藻類を培養し，これをメタン発酵の原 料として燃料を生産するシステムを検討した。

また，NASA では38)ホテイアオイ(ウォーターヒ ヤシンス, Eichhornia crassipes) やアオウキクサ(ダ ックウィード, Lemna または Spirodela) をラグー ンで栽培すると，これらの植物がラグーン中の栄養塩 を吸収したり，日光をさえぎることにより，藻類の増 殖を抑制し，増殖変動による水質悪化を防ぐことがで きるといら。また, それらの水生植物のメタン発酵も 検討されているそらである。ただし，ホテイアオイは 温带では冬期枯れてしまらのが問題である。NASAで はこのように，廃水処理システムと組み合わせた太陽 エネルギーの燃料化を検討しているだけではなく，以 前，家畜の飼料として日本から持ち込まれ雑草化した クズ (Pueraria) のメタン発酵も検討していると報道 された ${ }^{89}$ 。また, 米国では海藻（ジャイアントケルプ， Macrocystic pyrifera) のメタン発醏も検討されてい るといら ${ }^{40) 411 。}$

廃水や廃棄物を原料とするにしろ, 栽培植物を原料 とするにしろ, メタン発酵を実際に行う場合の一つの 重要な問題は温度管理である。メタン発酵は $30 \sim 40^{\circ} \mathrm{C}$ の中温域または $50 \sim 60^{\circ} \mathrm{C}$ の高温域をはずれると発酵速 度が非常に遅くなるので, どちらかの範囲内に槽内温 度を維持しなければならない。このため, 従来, し尿 処理や産業廃水処理用のメタン発酵槽はスチームによ り加温されている。このステームの発生に生成メタン が燃料として使われるが，そのエネルギー収支は，気 温, 原料の種類, 量, 温度, 負荷条件, 発酵槽の形状, 規模などに依存する。園田の試算によれば40)豚ふんを 原料とした場合, 冬期, 気温を $10^{\circ} \mathrm{C}$, 原料の温度 $10^{\circ} \mathrm{C}$ とし， $37^{\circ} \mathrm{C}$ の中温発酵を行らとすれば，約50頭の規模 
以上からエネルギー的に自給できるといら。産業廃水 処理の場合など廃熱が発酵槽の加温に利用できれば， 生成したメタンを加温に使わずにすをのである。ま た, 最近, 太陽熱をメタン発酵槽の加温に用いる研究 が上原ら ${ }^{43}$ とより行われ，外気温が 1 日中 $0{ }^{\circ} \mathrm{C}$ 位でる， 生成メタンを加温に用いる事なく, 太陽熱のみで 1 日 中, 発醳槽を $36^{\circ} \mathrm{C}$ 付近に保つ事に成功した。今後, こ のよらな複合プロセスがますます検討されることであ ろう。

\section{4. おわりに}

メタン発酵には, 廃水, 廃棄物処理プロセスとして の役割に加えて太陽エネルギーからの燃料生産プロセ スといら役割も加わららとしている。これらのプロセ スを他の廃水, 廃棄物処理プロセスや太陽エネルギー 利用プロセスと有機的に結合させる事が全体的な経済 性を向上させるために必要になってくるであろう。そ の総合システムの一例を図 3 亿示す。

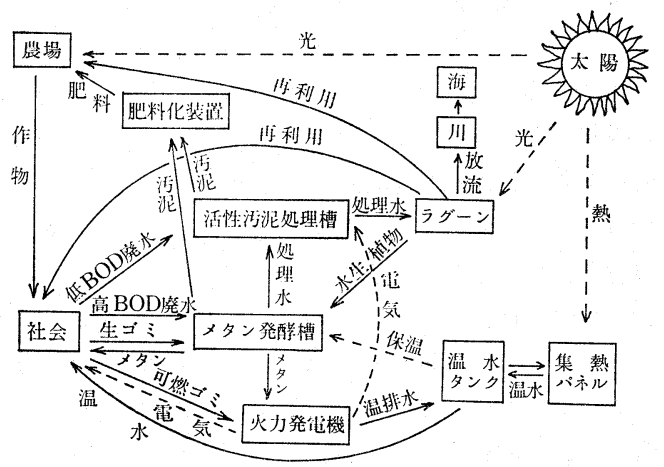

図 3 廃水, 廃塞物処理, 太陽エネルギー利用 総合システム

また，種々の有機質原料に対応した微生物代謝の制 御や微生物種や量の制御に関する知識の集積もますま す必要になってくると思われる。

な扮，本総説を書くにあたり，資料を提供して下さ った当研究所の方々㧤よび御校閲下さった応用技術部 長福岡誠一博士, 廃水処理研究室長太宰宙朗博士に深 謝致します。

\section{文 献}

1) T.C.Stadtman, Ann. Review of Microbiol.,

21, 121 (1967)

2) D.F.Toerien, W.H. J.Hattingh, Water Research, 3, 385 (1969)

3) R.S.Wolfe, Advances in Microbiol Physiol., 6, 107 (1971)

4) R.K. Thauer, K. Jungerman, K. Decker,
Bacteriol. Reviews, 41, 100 (1977)

5) J.G.Zeikus, Bacteriol. Reviews, 41, 514(1977)

6) S.Ghosh, M.L.Packer, A.C. Roess, J.R. Conrad, E.H. VanRyzin, J. WPCF, 49, 1019 (1977)

7) M.P. Bryant, "Bergey's Manual of Determinative Bacteriology", 8th ed., R.E. Buchanan, N.E. Gibbons, The Williams \& Wilkins Corp. Baltimore, p. 472 (1974)

8）園田，燃料協会誌， 55，666（1976）

9）太宰，“未来産業技術”，VOL. II，科学技術広報 財団, p.93 (1979)

10）小野，工業技術，20，54（1979）

11）岩井, 申, 名取, “下, 廃水污泥の処理”, コロナ 社 (1968)

12）須藤, “廃水処理の生物学”, 産業用水調査会, 第 9 章 嫌気性処理 (1977)

13) J.G.Zeikus, D. L. Henning, Antonie van Leeuwenhoek, 41, 543 (1975)

14) C. G. T.P.Schnellen, Dissertation, Technical University of Delft De Maasstad, Rotterdam (1947)

15) M.J. B. Paynter, R.E. Hungate, J. Bacteriol., 95, 1943 (1968)

16) P.H.Smith, R.E. Hungate, J. Bacteriol., 75, 713 (1958)

17) J.G.Zeikus, R.S.Wolfe, J. Bacteriol., 109, 707 (1972)

18) A.J.B.Zehnder, K.Wuhrmann, Arch. Microbiol., 111, 199 (1977)

19) M.P. Bryant, E.A.Wolin, M.J.Wolin, R.S. Wolfe, Arch. Microbiol., 59, 20 (1976)

20) T. C. Stadtman, H.A. Barker, J. Bacteriol., 61, 67 (1951)

21) R.A.Mah, M.R.Smith, L. Baresi, Appl. Environ. Microbiol., 35, 1174 (1978)

22) G. B. Patel, L. A. Roth, L. van den Berg, D.S. Clark, Can. J. Microbiol., 22, 1404 (1976)

23) R.S.Wolfe, Adv. Microbiol Physiol., 6, 107 (1971)

24) J.G.Zeikus, P. J.Weimer, D. R. Nelson, L. Daniels, Arch. Microbiol., 104, 129 (1975)

25) K. Decker, K. Jungermann, R. K. Thauer, Angew. Chem. Internat. Edit., 9, 138 (1970)

26) C. A. Reddy, M.P. Bryant, M. J.Wolin, 
J. Bacteriol., 109, 539 (1972)

27) C. C. Scheifinger, B. Linehan, M.J. Wolin, Appl. Microbiol., 29, 480 (1975)

28) P.J.Weimer, J.G.Zeikus, Appl. Environ. Microbiol., 33, 289 (1977)

29) M. P. Bryant, L. L. Campbell, C. A. Reddy, M. R. Crabill, Appl. Environ. Microbiol., 33, 289 (1977)

29) M. P. Bryant, L. L. Campbell, C. A. Reddy, M. R. Crabill, Appl. Environ. Microbiol., 33, 1162 (1977)

30) M. J.Lathan, M. J. Wolin, Appl. Environ. Microbiol., 34, 297 (1977)

31) M. Chen, M. J.Wolin, Appl. Environ. Microbiol., 34, 756 (1977)

32) D. M. Ward, R. A. Mah, I. R. Kaplan, $A p p l$. Environ. Microbiol., 35, 1185 (1978)
33）西出，工業技術，20，84（1979）

34）高松，工業技術，20，44（1979）

35) C. G. Golueke, W.J. Oswald, H. B. Gotaas, Appl. Microbiol., 5, 47 (1957)

36) C. G. Golueke, W. J. Oswald, Adv. Appl. Microbiol., 7, 219 (1959)

37) W.J. Oswald, C. G. Golueke, Adv. Appl. Microbiol., 2, 223 (1960)

38) B.C. Wolverton, R. C. McDonald, J. WPCF, 51, 305 (1979)

39）朝日新聞（夕刊）12月 7 日 (1979)

40）德山，“未来産業技術”, VOL. II，科学技術厇報 財団, p.836（1979）

41）山崎, 工業技術, 20, 41 (1979)

42）園田，産業公害，15，1006（1979）

43）上原, 吉野, 新田, クリーンジャパン, 18, 28 (1979)

\title{
Methane Production by Microorganisms
}

\author{
Kazuhiro TANAKA
}

(Fermentation Research Institute. Agency of lndustrial Science \& Technology)

SYNOPSIS : - Methane fermentation can be utilized as a fuel gas producing process from solar energy because plant-body can become the raw material for methane fermentation. The bacteria which cause methane fermentation can be grouped into methanogenic bacteria which produce methane and non-methanogenic bacteria which produce substrates for methanogenic bacteria. The substrates for methanogenic bacteria are hydrogen and carbon dioxide, acetate, formate, and methanol. Acetate is utilized only in the presence of hydrogen by some species of bacteria, and is utilized even in the absence of hydrogen by other species. The existence of bacteria which produce methane from propionate or $n$ butyrate is doubted. Some examples of symbiotic relation between methanogenic and nonmethanogenic bacteria are known. Methane fermentation of algae, water hyacinth, arrowroot, giant kelp etc. has been studied in U.S.A. In Japan methane fermentation of urban wastes has been studied. Now we are needed to carried out not only macroscopic studies on a total system of waste water treatment processes, iwastes treatment processes, and solar energyutilizing processes but also microscopic studies on the phenomenon of methane fermentation itself. 